\title{
EMERGENCE FLOW OF WEEDS AS THE RESULT OF TEMPERATURE AND LUMINOSITY CONDITIONS IN HILLY AREAS
}

\author{
FLUXO DE EMERGÊENCIA DE PLANTAS DANINHAS EM FUNÇÃO DE \\ CONDIÇÕES DE TEMPERATURA E LUMINOSIDADE EM SOLO DE COXILHA
}

\author{
Renan Ricardo ZANDONÁ ${ }^{1}$; Dirceu AGOSTINETTO ${ }^{1}$; André da Rosa ULGUIM ${ }^{2}$;+ Rogério \\ Costa CAMPOS ${ }^{3}$; Andrés Antonio Monge VARGAS ${ }^{4}$; Jéssica Dias Gomes da SILVA ${ }^{1}$ \\ 1. Federal University of Pelotas - UFPel, Plant Protection Department, Capão do Leão, RS, Brazil. renan_zandona@hotmail.com; \\ agostinetto.d@gmail.com; jessicadiasgomes@hotmail.com; 2. Federal University of Santa Maria - UFSM, Plant Protection Department, \\ Santa Maria, Brazil; 3. Federal University of Pelotas - UFPel), Physics and Mathematics Department, Capão do Leão, RS, Brazil; \\ 4. Universidad de Costa Rica, Crop Science Department, San Pedro, SJ, Costa Rica. andresantonio.monge@ucr.ac.cr.
}

\begin{abstract}
Levels of weed infestation can be inferred from climate information since every species requires specific conditions for its germination process. This study aimed to evaluate weed species and their emergence flow in hilly areas, when subjected to different environmental conditions of temperature and luminosity. Two experiments were carried out in a completely randomized design with four replications. In the first experiment, treatments used plastic films (no film; film just on top; partially closed film; and fully closed film), whereas the second experiment used black polyethylene covers $(0 ; 35 ; 50$; and $80 \%)$. Weed emergence in the area was monitored daily, until the establishment of the emergence flow. Soil temperature, solar radiation interception and soil moisture were also monitored. For the analysis of species subjected to every type and level of covers, phytosociological parameters and the emergence speed index were calculated. Data were submitted to analysis of covariance and, when they were significant, the Tukey test $(\mathrm{p} \leq 0.05)$ was applied. A hierarchical cluster analysis was performed to relate factors and experimental levels to distribution intervals of climate covariates. Increase of $8.5^{\circ} \mathrm{C}$ in soil temperature favors the emergence of crabgrass, while reducing the emergence of alexander grass, morning glory, beggartick and sida. The main species that adapted to decrease in temperature and solar radiation are sida, alexander grass and crab grass. Besides, decrease in radiation increases the number of magnoliopsida species and enables all species to establish faster.
\end{abstract}

KEYWORDS: Climate changes. Germination. Management.

\section{INTRODUCTION}

Since weed emergence takes place in different periods in agricultural areas, loss of control and consequent loss of productivity due to competition can easily happen. Besides, many weeds reach their reproductive stages, renew their seedbanks and, as a result, ensure their permanence in a certain area (WERLE et al., 2014a).

The seedbank and vegetative propagules in the soil constitute the main sources of weed regeneration in agricultural areas which usually have high amount of seeds from several species. Therefore, knowledge of issues related to the emergence flow, causes of dormancy and environmental factors involved in weed germination helps to choose management practices (WERLE et al., 2014a).

Germination of weed seeds is regulated by the interaction between their physiological condition and environmental ones (MONDO et al., 2010). Every species requires specific conditions of water, temperature, luminosity and oxygen availability for its germination process. Water influences weed germination since it is part of molecular structures, such as proteins and nucleic acids, besides lipids and carbohydrates; as a result, water is responsible for restrictions on the species growth and development (TAIZ et al., 2017).

When water which is available in the soil is enough for seed soaking, the main limiting factor in this process is temperature (ALI et al., 2013), since it alters the speed of water absorption and biochemical reactions that trigger cell metabolism, such as transport and distribution of reserves to seedlings (TAIZ et al., 2017). There are species whose germination process is favored by constant temperature, whereas others are favored by changes in this process. Therefore, the plant emergence rate in the soil depends on the optimal temperature variable among species - that enables seed germination (MYERS et al., 2004).

Luminosity is another factor that is involved in seed germination since it regulates seedling growth and development. Depending on their responses to luminosity, seeds are classified into 
three categories: positively, negatively or neutrally photoblastic ones. Light intensity, wavelength and photoperiod regulate the beginning of germination because the phytochrome interprets and translates light signs to gene expression, which triggers germination promoters (TAIZ et al., 2017).

Even though these external factors do not act independently, knowledge of environmental requirements for weed seed germination is fundamental to help interpret their ecological behavior in the field so as to develop strategies and manage weeds in cultivated areas (MONDO et al., 2010), besides enabling more competitive capacity to the culture and decreasing losses of productivity. Thus, phytosociological studies are important because they yield knowledge of populations and of the behavioral biology of species to found weed management plans.

Therefore, the hypothesis of this study was that the emergence flow of weeds, species frequency and population in agricultural areas may be altered in different environmental conditions. This study aimed at evaluating weed species and the emergence flow of weeds in hilly areas, when subjected to different environmental conditions of temperature and luminosity.

\section{MATERIAL AND METHODS}

Two experiments were carried out in one- $\mathrm{m}^{3}$ brick planters in a completely randomized design with four replications. They were conducted to enable temperature and radiation variations by establishing levels in both factors. The first experiment, named the "greenhouse" factor, enabled to simulate increase in temperature at different levels of free airflow obstruction, besides radiation penetration and trapping in the experimental unit. Levels of this factor were established by the cover of 150-micron-thick plastic film. Treatments had four levels of plastic films (no film; film just on top; partially closed film; and fully closed film). In the second experiment, the factor was "radiation incidence". Its levels were defined by black polyethylene covers (SOLPAK agro shade net) at four shading levels $(0 ; 35 ; 50$; and $80 \%)$.

Every treatment consisted of a $2.4 \mathrm{~m}$ long, $1.2 \mathrm{~m}$ wide and $0.5 \mathrm{~m}$ high tunnel-like structure that held the different types of covers, so that evaluations could be carried out inside it. The structure was assembled to enable bilateral openings, but the top cover and a lateral one were kept closed during evaluation.

Soil was collected up to $0.1 \mathrm{~m}$ deep in a hilly area to conduct seedbank renewal and $12 \mathrm{k}$ soil was added to the surface of every planter. In this area, the seedbank was composed of 14 weed species which belong to ten families and amount to about $73,543.03$ seeds per $\mathrm{m}^{-2}$ (Table 1 ).

Table 1. Weed species sorted by family, with scientific and common name and number of seeds $\mathrm{m}^{-2}$.

\begin{tabular}{cccc}
\hline Family & Scientific name & Comum name & Seeds $^{-2}$ \\
\hline Amaranthaceae & Amaranthus viridis & Green amaranth & 1.579 .22 \\
Asteraceae & Conyza spp. & Hairy fleabane & 331.13 \\
Asteraceae & Bidens pilosa & beggartick & 1.426 .39 \\
Brassicaceae & Raphanus sativus & Radish & 7.437 .59 \\
Cyperaceae & Cyperus spp. & Cyperus & 738.66 \\
Convolvulaceae & Ipomoea grandifolia & Morning glory & 2.750 .89 \\
Euphorbiaceae & Euphorbia heterophylla & Wild poinsettia & 2.241 .47 \\
Malvaceae & Sida rhombifolia & Sida & 3.795 .21 \\
Poaceae & Digitaria sp. & Crabgrass & 23.280 .69 \\
Poaceae & Eleusine indica & Indian goosegrass & 203.76 \\
Poaceae & Lolium multiflorum & Ryegrass & 967.90 \\
Poaceae & Urochloa plantaginea & alexander grass & 24.893 .02 \\
Rubiaceae & Richardia brasiliensis & Brazil pusley & 1.910 .34 \\
Solanaceae & Solanum americanum & Black nightshade & 1.986 .76 \\
\hline
\end{tabular}

Weed emergence in every experiment was monitored up to the establishment of the emergence flow and counted daily in an area that stretched over
$0.25 \mathrm{~m}^{2}$. Plants that emitted either their cotyledons or coleoptiles, at least one $\mathrm{cm}$ of aerial part, were considered emergent. They were then identified and 
Emergence flow...

marked with micro-stakes. Emergence counting took place at the beginning of the morning at mild temperatures. The side to be opened was chosen so that the soil never got any direct sunlight during the experiment.

The analysis of communities of species found in every type of cover only considered summer weeds. The following phytosociological parameters were determined: frequency (FRE), which enables the evaluation of species distribution in packages; population (POP), which is the amount of plants of every species per area unit; relative population (RPOP), which is the relation of every species with the other ones that are found in the area; and relative importance (RI), which shows the most important species in the area under study.

FRE was determined by the percentage scale from zero (0) to one hundred (100), corresponding to the species absence and presence in the samples. Regarding POP and RPOP, calculations were carried out by formulas proposed by Mueller-Dombos and Ellenberg (1974), as follows:

Population $(\mathrm{POP})=\frac{\text { Total number of individuals }}{\text { Total sampling area }\left(1 \mathrm{~m}^{2}\right)}$

Relative population $(\mathrm{RPOP})=\underline{\text { Population of the species } \times 100}$ Total population of the species

In order to calculate relative importance (RI), the formula of the importance value index proposed by Mueller-Dombos and Ellenberg (1974) was adapted:

Relative importance $(\mathrm{RI})=\underline{\mathrm{RPOP}+\text { ESI of the species } \mathrm{x} 100}$ RPOP + ESI of all species

In order to calculate the speed emergence index (SEI), the equation described by Popinigis (1985) was used:

$\mathrm{ESI}=\Sigma_{1}^{n}\left(\frac{N 1}{D 1 !}+\frac{N 2}{D 2}+\cdots+\frac{N n}{D n}\right)$

where N1 is the number of seedlings which emerged on the first day; $\mathrm{Nn}$ is the accumulated number of emerged seedlings; D1 is the first day of counting; and Dn is the number of days after sowing.

Climate elements related to every treatment were also evaluated throughout the period. Soil temperature was determined $2 \mathrm{~cm}$ deep by a datalogger (HOBO 2x External Temperature Data
ZANDONÁ, R. R. et al.

Logger). Solar radiation interception was measured as the population of photosynthetically active photon flux (unit) on the soil surface. It was quantified by a quantometer (LI-190 Quantum Sensor, LI-COR, USA), coupled with a porometer (LI-1600 LI-COR, USA). Gravimetric soil moisture was determined by the thermogravimetric method at the end of the experiment. Irrigation was carried out daily, depending on the field capacity of every experimental unit, by a sprinkler system.

Resulting data were analyzed in terms of normality and then submitted to the analysis of variance $(p \leq 0.05)$. When they were significant, means were compared by the Tukey's test $(\mathrm{p} \leq 0.05)$. A hierarchical cluster analysis was carried out to relate factors and experimental levels to distribution intervals of the following co-variables: accumulated soil temperature (Ast.); soil moisture (Sm.); and accumulation of radiation interception (Ari.). Ast. was determined by the sum of temperatures throughout the whole period, when they were above $10{ }^{\circ} \mathrm{C}$, since it is considered the base temperature (Tbase) for the emergence of these species (WERLE et al., 2014b), whereas Ari. was determined by the sum of incident radiation, except the one that was intercepted in the period.

The cluster analysis was carried out by the complete linkage method (MURTAGH; LEGENDRE, 2014). This method defines the distance between two clusters as the maximum distance among their individual components. In this study, it is the maximum distance among covariables Ast., Sm. and Ari. The Euclidean space was adopted to establish the distance metric, where the process follows a sequence of interactions in which clusters are successfully grouped at different distance levels. The process is repeated up to the moment in which a cluster with all observations is formed. The dendrogram enabled 1500 to be defined as the value of optimal height partition among different, but internally homogeneous groups.

\section{RESULTS AND DISCUSSION}

The analysis of results found by the experiments showed that data transformation is not necessary, based on Shapiro-Wilk's and Hartley's tests. Regardless of their levels, covers under investigation (plastic film and agro shade nets) led to changes in temperature and luminosity in both experiments (Figures 1A and B). 


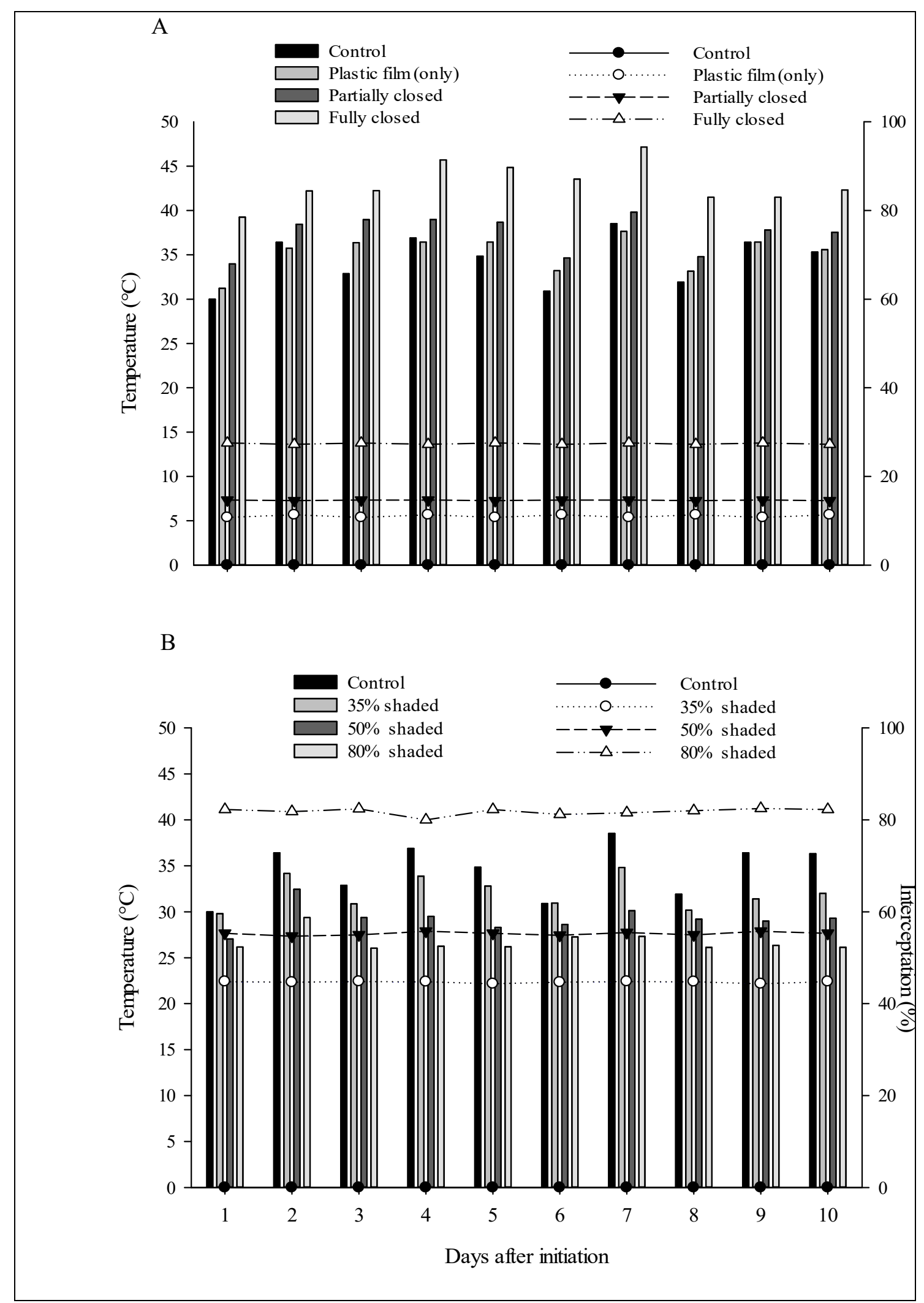

Figure 1. Daily temperature average of soil from hilly area and the interception of solar radiation in plastic film (A) and shade net (B).

In the experiment carried out with plastic film cover, increase in the closure levels enabled temperature increase. In the fully closed treatment, the temperature was, on average, $8.5^{\circ} \mathrm{C}$ higher than the one in the witness with no cover and with about $28 \%$ radiation interception (Figure $1 \mathrm{~A}$ ). On the other hand, the cover with an agro shade net had an inverse effect, i. e., the higher the shading levels, the 
lower the temperature. Thus, when interception was $80 \%$, the temperature decreased $7.8 \%$ by comparison with the witness with no cover (Figure 1B).

Soil moisture was also influenced by different types of covers, i. e., both led to decrease in moisture loss by evapotranspiration (Table 2). Regarding plastic films, the fully closed treatment led to an increase of $4 \%$ in moisture by comparison with the witness. However, $80 \%$ shading kept soil moisture $10 \%$ above the one of the witness.

Table 2. Temperature $\left({ }^{\circ} \mathrm{C}\right)$, interception of solar radiation (\%) and soil moisture (\%) of hilly soil, at different levels of closing with plastic film and shading.

\begin{tabular}{lccc}
\hline Treatment & Temperature $\left({ }^{\circ} \mathbf{C}\right)$ & Interception (\%) & Soil moisture (\%) \\
\hline No film & $34.5 \mathrm{c}^{1}$ & $0.0000 \mathrm{~d}$ & $21.2 \mathrm{~b}$ \\
Film just on top & $35.2 \mathrm{c}$ & $0.1075 \mathrm{c}$ & $21.2 \mathrm{~b}$ \\
Partially closed film & $36.8 \mathrm{~b}$ & $0.1467 \mathrm{~b}$ & $21.7 \mathrm{ab}$ \\
Fully closed film & $43.0 \mathrm{a}$ & $0.2753 \mathrm{a}$ & $22.1 \mathrm{a}$ \\
\hline C.V. $(\%)$ & 1.06 & 0.66 & 1.78 \\
\hline No shading & $34.5 \mathrm{a}$ & $0.0000 \mathrm{~d}$ & $21.0 \mathrm{c}$ \\
35\% shaded & $32.3 \mathrm{~b}$ & $0.4481 \mathrm{c}$ & $21.7 \mathrm{bc}$ \\
50\% shaded & $29.0 \mathrm{c}$ & $0.5534 \mathrm{~b}$ & $22.6 \mathrm{ab}$ \\
80\% shaded & $26.7 \mathrm{~d}$ & $0.8227 \mathrm{a}$ & $23.1 \mathrm{a}$ \\
\hline C.V. $(\%)$ & 0.95 & 0.81 & 3.17 \\
\hline
\end{tabular}

${ }^{1}$ Means followed by the same letter within a column are not different according to the Tukey's test $(\mathrm{p} \leq 0.05)$.

These changes were expected since treatments with plastic film cover were established to promote temperature increase, which is a tendency in climate changes, due to $\mathrm{CO}_{2}$ increase in the atmosphere (IPCC, 2019). These conditions are typical of the "greenhouse effect". Likewise, agro shade nets were established to promote changes in the amount of light, another tendency in the following years, since there has been decrease in solar radiation due to changes in the composition of the atmosphere and clouds, caused by pollutant gases, such as $\mathrm{CO}_{2}$ and aerosols (BARRETT et al., 2014; IPCC, 2019). Therefore, the species behavior was affected by the conditions imposed by the treatments, which could predict both the behavior and adaptation of plants that may become more important in hilly areas.

Both experiments showed the predominance of five species which belong to four different families: Poaceae, Convolvulaceae, Asteraceae and Malvaceae. There was $58.3 \%$ decrease in the emergence of species and only $44.4 \%$ was weed species from summer cultures, by comparison with the seedbank (Table 1). In the experiment with plastic film, the species Urochloa plantaginea (L.) (alexander grass), Digitaria spp. (L.) (crabgrass), Ipomoea grandifolia (L.) (morning glory), Bidens pilosa (L.) (beggartick) and Sida rhombifolia (L.) (sida) showed significance in variables EMG, POP, RPOP and RI (Table 3). The variable ESI did not show any significance in the case of morning glory.

Table 3. Weed phytosociological parameters identifies in soil from hilly area, at different levels of closing with plastic film.

\begin{tabular}{lccccc}
\hline & $\begin{array}{c}\text { Urochloa } \\
\text { plantaginea }\end{array}$ & $\begin{array}{c}\text { Digitaria } \\
\text { spp. }\end{array}$ & $\begin{array}{c}\text { Ipomoea } \\
\text { spp. }\end{array}$ & $\begin{array}{c}\text { Bidens } \\
\text { pilosa }\end{array}$ & $\begin{array}{c}\text { Sida } \\
\text { rhombifolia }\end{array}$ \\
\hline Treatment & $78 \mathrm{a}$ & $83 \mathrm{~b}$ & $9 \mathrm{a}$ & $4 \mathrm{a}$ & $10 \mathrm{a}$ \\
\hline No film & $83 \mathrm{a}$ & $93 \mathrm{~b}$ & $10 \mathrm{a}$ & $0 \mathrm{~b}$ & $13 \mathrm{a}$ \\
Film just on top & $78 \mathrm{a}$ & $156 \mathrm{a}$ & $4 \mathrm{~b}$ & $0 \mathrm{~b}$ & $4 \mathrm{~b}$ \\
Partially closed film & $30 \mathrm{~b}$ & $211 \mathrm{a}$ & $4 \mathrm{~b}$ & $0 \mathrm{~b}$ & $0 \mathrm{c}$ \\
Fully closed film & 8.0 & 20.7 & 27.9 & 16.5 & 26.4 \\
\hline C.V. (\%) & $100^{2}$ & 100 & 100 & 25 & 75 \\
\hline No film & 100 & 100 & 50 & 0 & 75 \\
Film just on top & 100 & 100 & 35 & 0 & 50 \\
Partially closed film & & \multicolumn{5}{c}{ - }
\end{tabular}




\begin{tabular}{|c|c|c|c|c|c|}
\hline Fully closed film & 100 & 100 & 35 & 0 & 0 \\
\hline & \multicolumn{5}{|c|}{ Population (POP $-\mathbf{m}^{2}$ ) } \\
\hline No film & \multicolumn{5}{|c|}{$184.0 \mathrm{c}$} \\
\hline Film just on top & \multicolumn{5}{|c|}{$199.0 \mathrm{~b}$} \\
\hline Partially closed film & \multicolumn{5}{|c|}{$242.0 \mathrm{a}$} \\
\hline Fully closed film & \multicolumn{5}{|c|}{$245.0 \mathrm{a}$} \\
\hline \multirow[t]{2}{*}{ C.V. $(\%)$} & \multicolumn{5}{|c|}{15.0} \\
\hline & \multicolumn{5}{|c|}{ Relative population (RPOP \%) } \\
\hline No film & $42.4 \mathrm{a}$ & $45.1 \mathrm{c}$ & $4.8 \mathrm{a}$ & $2.2 \mathrm{a}$ & $5.5 \mathrm{a}$ \\
\hline Film just on top & $41.5 \mathrm{~b}$ & $46.7 \mathrm{c}$ & $5.1 \mathrm{a}$ & $0.0 \mathrm{~b}$ & $6.3 \mathrm{a}$ \\
\hline Partially closed film & $32.1 \mathrm{c}$ & $64.5 \mathrm{~b}$ & $1.7 \mathrm{~b}$ & $0.0 \mathrm{~b}$ & $1.7 \mathrm{~b}$ \\
\hline Fully closed film & $12.2 \mathrm{~d}$ & $86.1 \mathrm{a}$ & $1.7 \mathrm{~b}$ & $0.0 \mathrm{~b}$ & $0.0 \mathrm{~b}$ \\
\hline \multirow[t]{2}{*}{ C.V. $(\%)$} & 12.4 & 8.8 & 21.6 & 32.6 & 37.2 \\
\hline & \multicolumn{5}{|c|}{ Speed of Emergence index (SEI) } \\
\hline No film & $10.9 \mathrm{a}$ & $10.6 \mathrm{~b}$ & $1.2^{\mathrm{ns}}$ & $0.5 \mathrm{a}$ & $1.3 \mathrm{~b}$ \\
\hline Film just on top & $11.1 \mathrm{a}$ & $10.4 \mathrm{~b}$ & 1.3 & $0.0 \mathrm{~b}$ & $1.9 \mathrm{a}$ \\
\hline Partially closed film & $10.0 \mathrm{a}$ & $20.6 \mathrm{a}$ & 0.5 & $0.0 \mathrm{~b}$ & $0.4 \mathrm{c}$ \\
\hline Fully closed film & $3.3 \mathrm{~b}$ & $24.7 \mathrm{a}$ & 0.9 & $0.0 \mathrm{~b}$ & $0.0 \mathrm{c}$ \\
\hline \multirow[t]{2}{*}{ C.V. $(\%)$} & 8.9 & 22.2 & 41.1 & 18.4 & 28.5 \\
\hline & \multicolumn{5}{|c|}{ Relative importance (RI - \%) } \\
\hline No film & $42.8 \mathrm{a}$ & $44.7 \mathrm{c}$ & $4.8 \mathrm{a}$ & $2.2 \mathrm{a}$ & $5.5 \mathrm{a}$ \\
\hline Film just on top & $42.4 \mathrm{a}$ & $45.8 \mathrm{c}$ & $5.2 \mathrm{a}$ & $0.0 \mathrm{~b}$ & $6.6 \mathrm{a}$ \\
\hline Partially closed film & $32.0 \mathrm{~b}$ & $64.6 \mathrm{~b}$ & $1.8 \mathrm{~b}$ & $0.0 \mathrm{~b}$ & $1.6 \mathrm{~b}$ \\
\hline Fully closed film & $12.0 \mathrm{c}$ & $86.0 \mathrm{a}$ & $2.0 \mathrm{~b}$ & $0.0 \mathrm{~b}$ & $0.0 \mathrm{~b}$ \\
\hline C.V. $(\%)$ & 11.6 & 9.8 & 24.3 & 31.9 & 36.0 \\
\hline
\end{tabular}

${ }^{\mathbf{1}}$ Means followed by the same letter within a column are not different according to the Tukey's test $(\mathrm{p} \leq 0.05) .{ }^{2}$ Percentage of presence $(100)$ and absence $(0)$ of the species in the sample.

Most species had weed EMG decreased as the result of increase in levels of plastic film closure. Emergence of alexander grass and morning glory decreased $61.5 \%$ and $55.6 \%$, respectively, in the fully closed treatment, whereas neither beggartick nor sida emerged in these conditions. Decrease in the emergence of these species may have been caused by a significant increase in the temperature, since it reached $43{ }^{\circ} \mathrm{C}$ (Table 2).

High temperature may have caused thermal stress in seeds and prevented germination from happening (CANOSSA et al., 2008), since their germination temperature ranges from 18 and $32{ }^{\circ} \mathrm{C}$, $\pm 3^{\circ} \mathrm{C}$ (WERLE et al., 2014b; CHIVINGE, 1996). Tridax procumbens (L.) had similar results, i. e., from 25 to $35^{\circ} \mathrm{C}$, germination was above $90 \%$, but at $40{ }^{\circ} \mathrm{C}$, it was null (GUIMARÃES; SOUZA; PINHO, 2000). When temperature is above the optimal one, there is decrease in oxygen, enzyme activity and RNA, DNA, sugar and ATP syntheses. It leads to enzyme coagulation and seed deterioration and death (SMITH et al., 1992).

Crab grass EMG increased $154.2 \%$ in the treatment with fully closed cover by comparison with the witness (Table 3 ). The increase is related to the high daily thermal amplitude of the treatment which provided better germination conditions, thus, corroborating results found by Mondo et al. (2010). They reported that the thermal amplitude of the genus Digitaria is $15^{\circ} \mathrm{C}$ and that its highest germination percentages take place at alternate temperatures from 20 to $35^{\circ} \mathrm{C}$ and from 15 to $35^{\circ} \mathrm{C}$ in the presence of luminosity. According to the authors, in the case of species that have high germination at alternate temperatures, temperature amplitude is more important than absolute temperature values.

Concerning the frequency of species covered by plastic film, the more the closure levels increased, the more the distribution and incidence of magnoliopsida species decreased. In the fully closed treatment, morning glory was the only magnoliopsida species that emerged; it was found in only $35 \%$ of samples. Therefore, results of this study show that, if the temperature reaches $43{ }^{\circ} \mathrm{C}$ (Table 2), these species do not prevail. However, both alexander grass and crab grass could be found at all closure levels, an evidence of the fact that 
these species became predominant. Besides, they could be found in $100 \%$ of samples in the fully closed treatment (Table 3).

Increase in closure levels resulted in an increase in the total population of species used by the experiment (Table 3). In the fully closed treatment, the increase was about $33.2 \%$, by comparison with the witness. However, RPOP of most species in the area decreased as the result of increase in closure levels, except in the case of crab grass, which increased $90.9 \%$ in the fully closed area, by comparison with the witness. Low populations of most species can be attributed to the high temperature, which did not favor their emergence, to release of allelopathic compounds and/or to interspecific competition exerted by the dominant species - which inhibited germination of other species.

ESI of alexander grass decreased $69.7 \%$, whereas the ones of beggartick and sida reduced $100 \%$ when temperature increased, by comparison with the witness and the fully closed treatment (Table 3). However, in the case of crab grass, increase in the closure levels of plastic film led to high ESI, a fact that shows that conditions are more favorable to break dormancy at $43{ }^{\circ} \mathrm{C}$ (Table 2). Thus, in the fully closed treatment, there was a temperature increase of $8.5{ }^{\circ} \mathrm{C}$, which resulted in an increase of $133 \%$ in the ESI of crab grass. Increase in temperature is believed to break crab grass dormancy and lead to better establishment in the field and advantages when it competes with other cultures. On the other hand, it decreases the
ZANDONÁ, R. R. et al.

establishment of other plants, a fact that may enable the use of more selective herbicides whose spectrum is narrower. Besides, production costs may be reduced and impact on the environment may be mitigated.

Crab grass was the most important weed in this study, regardless of the closure levels with plastic film (Table 3). The fully closed treatment led to an increase of $92.4 \%$ in the RI of crab grass, by comparison with the witness. Alexander grass was the second most important species in the area. Increase in closure levels reduced its importance, e. g., the fully closed treatment led to a decrease of $71.9 \%$, by comparison with the witness. Morning glory, beggartick and sida were the least important species in the area and also lost importance as closure levels of plastic film increased. Predominance of crab grass and alexander grass may be attributed to the large seedbank found in the area in previous cultures and in the determination of the seedbank (Table 1).

In the experiment with agro shade nets, all variables were significant in both species (Table 4). Increase in the shading levels led to higher EMG in all weeds in the area than the one of plants with no cover (witness). Decrease of $80 \%$ in light intensity enabled an increase of $158.9 \%$ in alexander grass emergence (Table 4). These data corroborate the ones found in the literature, which infers that this species is considered neutrally photoblastic, since it may germinate with or without exposure to light (SALVADOR et al., 2007). Its optimal germination temperature is $26^{\circ} \mathrm{C}$.

Tabela 4. Weed phytosociological parameters identifies in soil from hilly area, at different levels of shading.

\begin{tabular}{|c|c|c|c|c|c|}
\hline & $\begin{array}{c}\text { Urochloa } \\
\text { plantaginea }\end{array}$ & Digitaria spp. & $\begin{array}{l}\text { Ipomoea } \\
\text { spp. }\end{array}$ & $\begin{array}{l}\text { Bidens } \\
\text { pilosa }\end{array}$ & Sida rhombifolia \\
\hline Treatment & \multicolumn{5}{|c|}{ Total number of emergence (EMG - $\mathbf{m}^{2}$ ) } \\
\hline No shading & $78 \mathrm{c}^{1}$ & $83 \mathrm{c}$ & $7 \mathrm{~b}$ & $4 \mathrm{c}$ & $10 \mathrm{~d}$ \\
\hline $35 \%$ shaded & $75 \mathrm{c}$ & $103 \mathrm{~b}$ & $8 \mathrm{~b}$ & $15 \mathrm{~b}$ & $123 \mathrm{c}$ \\
\hline $50 \%$ shaded & $120 \mathrm{~b}$ & $100 \mathrm{~b}$ & $9 \mathrm{~b}$ & $24 \mathrm{a}$ & $202 \mathrm{~b}$ \\
\hline $80 \%$ shaded & $202 \mathrm{a}$ & $147 \mathrm{a}$ & $18 \mathrm{a}$ & $20 \mathrm{ab}$ & $241 \mathrm{a}$ \\
\hline \multirow[t]{2}{*}{ C.V. $(\%)$} & 5.5 & 8.7 & 28.6 & 22.4 & 4.9 \\
\hline & \multicolumn{5}{|c|}{ Frequency (\%) } \\
\hline No shading & $100^{2}$ & 100 & 75 & 75 & 75 \\
\hline $35 \%$ shaded & 100 & 100 & 100 & 75 & 100 \\
\hline $50 \%$ shaded & 100 & 100 & 75 & 100 & 100 \\
\hline $80 \%$ shaded & 100 & 100 & 75 & 100 & 100 \\
\hline & \multicolumn{5}{|c|}{ Population (POP $-\mathrm{m}^{2}$ ) } \\
\hline No shading & \multicolumn{5}{|c|}{$182.0 \mathrm{~d}$} \\
\hline $35 \%$ shaded & \multicolumn{5}{|c|}{$324.0 \mathrm{c}$} \\
\hline $50 \%$ shaded & \multicolumn{5}{|c|}{$455.0 \mathrm{~b}$} \\
\hline $80 \%$ shaded & \multicolumn{5}{|c|}{$628.0 \mathrm{a}$} \\
\hline C.V. $(\%)$ & \multicolumn{5}{|c|}{3,80} \\
\hline
\end{tabular}




\begin{tabular}{lccccc}
\hline No shading & $42.9 \mathrm{a}$ & $45.6 \mathrm{a}$ & $3.8 \mathrm{a}$ & $2.2 \mathrm{c}$ & $5.5 \mathrm{c}$ \\
$35 \%$ shaded & $23.1 \mathrm{c}$ & $31.8 \mathrm{~b}$ & $2.5 \mathrm{c}$ & $4.6 \mathrm{a}$ & $38.0 \mathrm{~b}$ \\
$50 \%$ shaded & $26.3 \mathrm{c}$ & $22.0 \mathrm{c}$ & $2.0 \mathrm{c}$ & $5.3 \mathrm{a}$ & $44.4 \mathrm{a}$ \\
$80 \%$ shaded & $32.2 \mathrm{~b}$ & $23.4 \mathrm{c}$ & $2.9 \mathrm{~b}$ & $3.2 \mathrm{~b}$ & $38.4 \mathrm{~b}$ \\
C.V. (\%) & 5.3 & 11.1 & 30.1 & 28.6 & 5.3 \\
\hline & \multicolumn{6}{c}{ Speed Emergence index (SEI) } \\
\hline No shading & $10.9 \mathrm{c}$ & $10.6 \mathrm{c}$ & $1.9 \mathrm{~b}$ & $0.5 \mathrm{c}$ & $1.3 \mathrm{~d}$ \\
$35 \%$ shaded & $13.3 \mathrm{c}$ & $14.0 \mathrm{~b}$ & $1.9 \mathrm{~b}$ & $1.9 \mathrm{~b}$ & $15.7 \mathrm{c}$ \\
$50 \%$ shaded & $21.6 \mathrm{~b}$ & $14.4 \mathrm{~b}$ & $2.6 \mathrm{~b}$ & $3.4 \mathrm{a}$ & $26.1 \mathrm{~b}$ \\
$80 \%$ shaded & $43.5 \mathrm{a}$ & $20.3 \mathrm{a}$ & $4.4 \mathrm{a}$ & $2.7 \mathrm{ab}$ & $34.5 \mathrm{a}$ \\
C.V. (\%) & 20.8 & 9.3 & 25.5 & 21.2 & 8.09 \\
\hline \multicolumn{7}{c}{ Relative importance (RI - \%) } \\
\hline No shading & $42.9 \mathrm{a}$ & $44.9 \mathrm{a}$ & $4.6 \mathrm{a}$ & $2.2 \mathrm{n}$ & $5.4 \mathrm{c}$ \\
$35 \%$ shaded & $24.8 \mathrm{c}$ & $31.2 \mathrm{~b}$ & $3.0 \mathrm{~b}$ & 4.4 & $36.6 \mathrm{~b}$ \\
$50 \%$ shaded & $28.5 \mathrm{c}$ & $21.7 \mathrm{c}$ & $2.7 \mathrm{~b}$ & 5.2 & $41.9 \mathrm{a}$ \\
$80 \%$ shaded & $36.7 \mathrm{~b}$ & $21.3 \mathrm{c}$ & $3.6 \mathrm{~b}$ & 2.9 & $35.5 \mathrm{~b}$ \\
C.V. (\%) & 14.1 & 13.1 & 39.1 & 45.3 & 6.1 \\
\hline
\end{tabular}

${ }^{1}$ Means followed by the same letter within a column are not different according to the Tukey's test ( $\left.\leq \leq 0.05\right) .{ }^{2}$ Percentage of presence (100) and absence (0) of the species in the sample.

Crab grass is also considered neutrally photoblastic (MONDO et al., 2010), even though its EMG increase was just $77.1 \%$ in the treatment with $80 \%$ shading, by comparison with the witness (Table 4). Unlike alexander grass, which needs optimal germination temperature, crab grass needs higher temperature variation (MONDO et al., 2010), but it did not occur due to increase in interception levels.

Morning glory and sida, which are considered negatively photoblastic (ORZARI et al., 2013), had EMG increases of 157.1 and 2,310.0\%, respectively, when treated with $80 \%$ shading, by comparison with no shading (Table 4). In the treatment with $80 \%$ shading, the temperature was also close to the one required for the germination of these species, i. e., $27.5{ }^{\circ} \mathrm{C}$ for morning glory (ORZARI et al., 2013) and $30{ }^{\circ} \mathrm{C}$ for sida (CARDOSO, 1990).

Increase in shading levels also increased beggartick EMG (Table 4). Increases of 500 and $400 \%$ in its EMG were reached with 50 and $80 \%$ shading, respectively, by comparison with the witness. This species is considered positively photoblastic, even though beggartick germination may occur without exposure to light (KLEIN; FELLIPE, 1991), since achenes with verrucose tegument show dormancy and sensitivity to light but achenes with no tegument ornament do not (AMARAL; TAKAKI, 1998). Besides, responses to light are not absolute, i. e., most positively photoblastic species show some germination when they are not exposed to light in laboratories (KLEIN; FELLIPE, 1991).
Variation in germination is a capacity that has useful ecological consequences because, in areas with mulch, the physical effect of straw decreases the passage of solar radiation and the thermal amplitude on the superficial layer of the soil. Even so, some seeds germinate in any condition of luminosity (KLEIN; FELLIPE, 1991). Since the shading effect caused changes in temperature, the highest beggartick emergence also occurred in the treatment with $80 \%$ interception. The mean temperature was close to $25{ }^{\circ} \mathrm{C}$, which is considered optimal for the germination of the species (CHIVINGE, 1996).

Conditions of soil temperature reflect results found in all species. The highest emergence of plants occurred when light intensity decreased. It showed the behavior of negatively and neutrally photoblastic species but it also happened because of the decrease in temperature resulting from the treatments, which provided either optimal temperatures or a range of best germination (Table 2).

Frequency of species in the area covered by agro shade net was only altered in the cases of beggartick and sida, whose frequency increased $25 \%$ in the samples as shading levels increased (Table 4). Thus, decrease of $80 \%$ in shading led to high distribution of species in the area, mainly magnoliopsida species.

The total population of species in the experiment with agro shade nets increased about $270 \%$ in the treatment with $80 \%$ shading, by comparison with the witness (Table 4). Increase in the weed population per area expands the possibility of success related to plant establishment and 
development, a fact that ensures the permanence of the species in the area and increases interspecific competition by providing high level of competition and damage in cultures, thus, more control is needed. On the other hand, it is harmed by increase in intraspecific competition and the possibility of self-thinning because plants have innate capacity for adjusting when the space that is available for the exploitation of resources in the environment is limited. This phenomenon was shown by Yoda et al. (1963), who named it " $3 / 2$ power rule", in agreement with the relation between plant weight and the population that develops in response to mortality.

All species showed increase in emergence, but RPOP of most plants in the area decreased as shading levels increased (Table 4). However, both beggartick and sida had maximum RPOP in the treatment with $50 \%$ shading, i. e., increases of 242.8 and $714.0 \%$, respectively. Minimum RPOP of alexander grass was found in the treatment with $35 \%$ shading, whereas crab grass and morning glory got their minimum values with $50 \%$ shading. Both alexander grass and crab grass were the species with the highest populations, i. e., 42.9 and $45.6 \mathrm{plants} / \mathrm{m}^{-}$ ${ }^{2}$, respectively, when there was no shading. In the case of $80 \%$ shading, sida had the highest population, followed by alexander grass and crab grass.

ESI's of all species increased as shading levels increased (Table 4). When shading was $80 \%$, ESI of alexander grass, the species with the fastest establishment at this level, reached $43.5 \%$. Crab grass had ESI increase of $91.5 \%$ in the treatment with $80 \%$ shading, by comparison with the witness. As a result, it is one of the species with the fastest establishment in the area. Sida, which increased $2,553.8 \%$, was the most favored species by the increase in shading levels. In the treatment with $80 \%$ shading, morning glory had an ESI increase of
$57 \%$, by comparison with the average of three levels with no difference.

Beggartick was the species with the lowest ESI, even though increases of 50 and $80 \%$ in shading levels led to increases of 600.0 and $440.0 \%$, respectively, by comparison with the witness. It may be inferred that increase in shading enables dormancy to be broken and the establishment of these species in hilly areas, influencing crop management in agricultural cultures.

Alexander grass, crab grass and morning glory lost importance as shading levels increased, whereas beggartick was not affected (Table 4). However, sida got importance when shading levels increased and was the most relevant species at interception levels of 35 and $50 \%$. When interception was $80 \%$, it was only below alexander grass. Thus, both species tend to adapt to decrease in luminosity.

As shading increased, magnoliopsida species became more important and increased from $12 \%$ in the witness treatment to $42 \%$ in the treatment with $80 \%$ shading. However, even though liliopsida species had a decrease of $66 \%$ in importance in treatments with $80 \%$ shading, by comparison with the witness, they were the most relevant ones due to their large seedbank.

Results of group distribution with similar behavior patterns by the cluster method and the grouping analysis, which were based on temperature accumulation (Ta.), radiation interception accumulation (Ra.) and soil moisture (Sm.), separated the treatments into four groups with similar behavior within groups but divergent one among them. Association was 0.85 (Figure 2). According to Murtagh and Legendre (2014), this analysis is subjective and may generate difficulty in group separation, even though it is easily interpreted in data analyses because the visual examination of spots should occur where changes in levels enable group delimitation. 


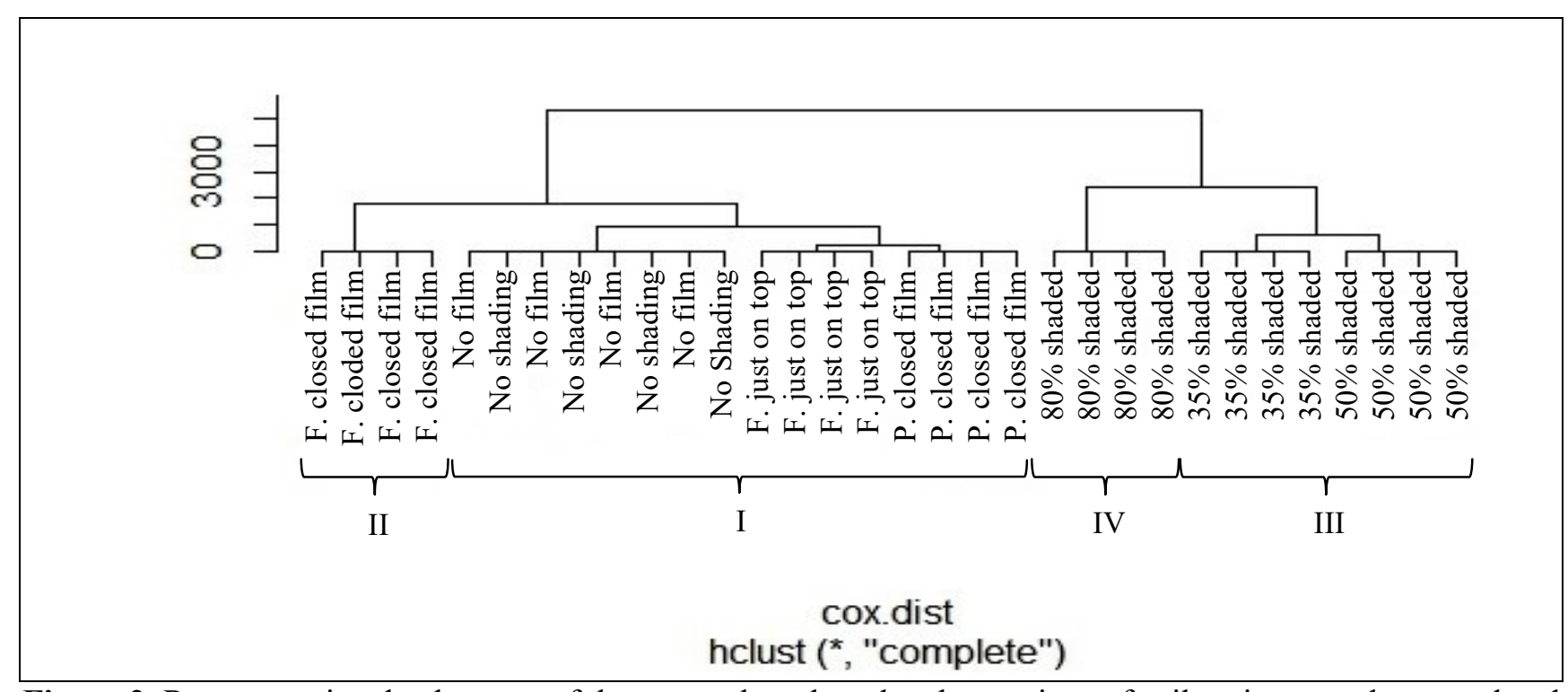

Figure 2. Representative dendrogram of the groups based on the observations of soil moisture and accumulated temperature and solar radiation by the agglomerative hierarchical method, using Cluster as the dissimilarity measures. Group I: accumulated Temperature (Ta) $251^{\circ} \mathrm{C}$, accumulated radiation (Ra). $6.158 \mathrm{cal}^{\mathrm{cm}} \mathrm{cm}^{-2}$ and soil moisture (Sm) $21 \%$; Group II: Ta. $332^{\circ} \mathrm{C}$, Ra. $4,460 \mathrm{calccm}^{-2}$ and Su: $22 \%$; Group III: Ta. $208^{\circ} \mathrm{C}$, Ra. $3,210 \mathrm{cal}^{-\mathrm{cm}^{-2}}$ and Su 22\%; Group IV: Ta. $169^{\circ} \mathrm{C}$, Ra. $1,140 \mathrm{cal}^{-\mathrm{cm}^{-2}}$ and Su $23 \%$.

According to Murtagh and Legendre (2014), a cut in the dendrogram at the height of 1500 , by a visual examination of the spot where changes in levels occurred, detected four groups. Group I consists of treatments with no film, film just on top, partially closed and no shading, whose temperature accumulation was about $251^{\circ} \mathrm{C}$, and had the highest accumulation of radiation $\left(6,158 \mathrm{cal} . \mathrm{cm}^{-2}\right)$ and the lowest soil moisture (21\%). Group II comprises only the fully covered treatment; it had the highest temperature accumulation $\left(332^{\circ} \mathrm{C}\right)$ and decrease of $24 \%$ in radiation, but soil moisture close to $22 \%$. Group III includes treatments with 35 and 50\% shading. There was decrease of $17 \%$ in temperature accumulation and of about $50 \%$ in radiation accumulation, but soil moisture was close to $22 \%$. Group IV is the treatment with $80 \%$ shading, the lowest temperature accumulation $\left(169^{\circ} \mathrm{C}\right)$ and radiation accumulation $\left(1,140 \mathrm{cal}^{-\mathrm{cm}^{-2}}\right)$, but high soil moisture $(23,1 \%)$.

Climate conditions in Group I show that, these days, species that belong to the Poaceae family have the largest populations of weeds in hilly areas and that crab grass and alexander grass are still the most important species, if there is no change in management systems and climate conditions (Figure 3). According to the Intergovernmental Panel on Climate Changes (IPCC, 2019), there will increase in concentrations of greenhouse gases and, consequently, there may be increase in temperature and/or decrease in luminosity due to accumulation of solid and gaseous particles in the atmosphere. Therefore, if climate conditions reach proportions found in Group II, with increase of about 32\% in temperature accumulation and decrease of $24 \%$ in solar radiation accumulation, there will be decrease in the emergence of both weed classes in hilly areas (Figure 3). In these conditions, crab grass and alexander grass will be the most important species in dry cultivated areas, where emergence will be about 110 and 30 plants $\mathrm{m}^{-2}$, respectively. There will be neither emergence of beggartick nor sida in these conditions, but morning glory may germinate as low populations. 


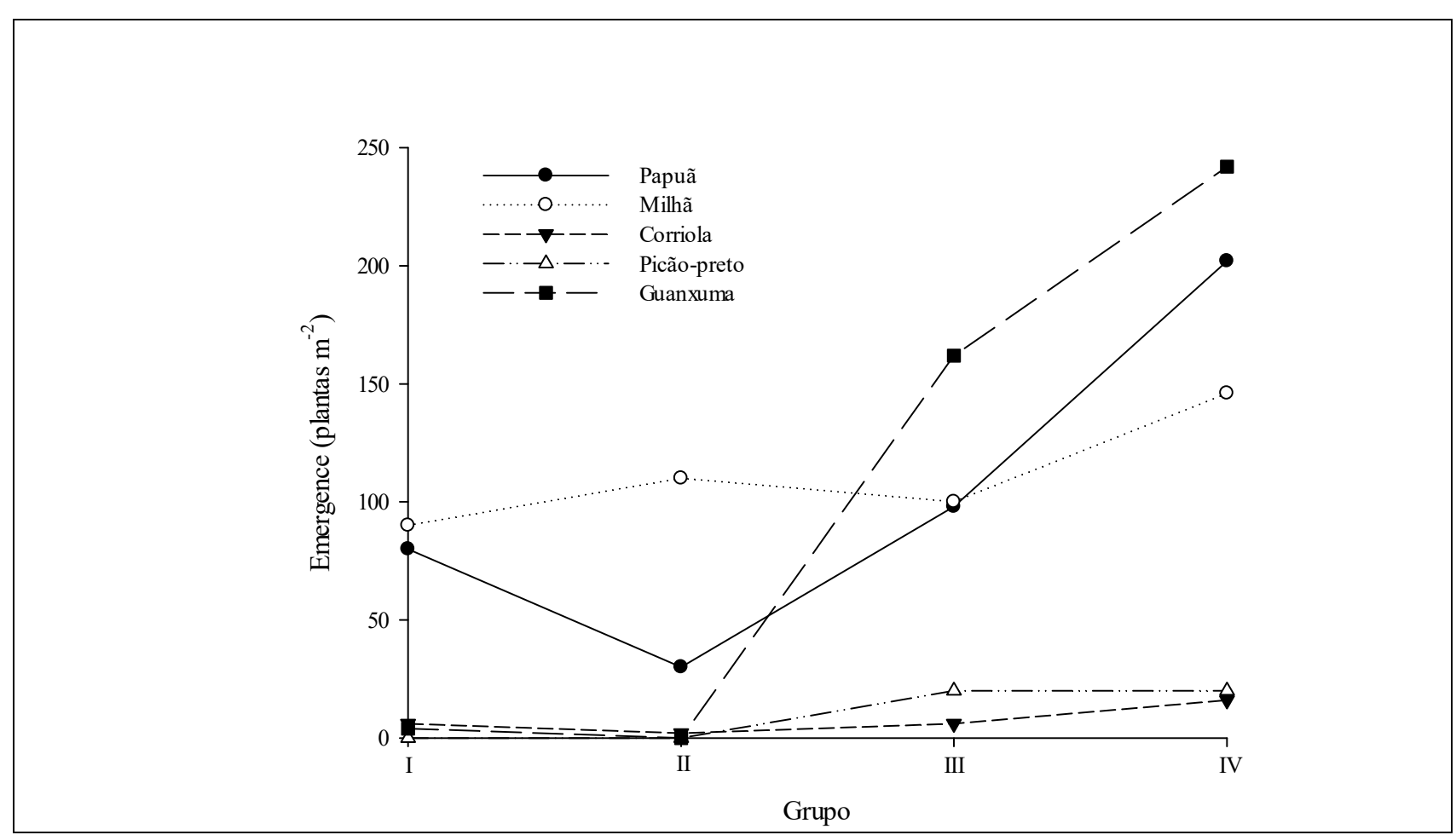

Figure 3. Weed emergence according to the grouping characteristics, based on accumulated temperature, accumulated solar radiation and soil moisture. Group I: accumulated temperature (Ta) $251^{\circ} \mathrm{C}$, accumulated radiation (Ra). $6.158 \mathrm{cal}^{-\mathrm{cm}^{-2}}$ and soil moisture (Sm) $21 \%$; Group II: Ta. $332^{\circ} \mathrm{C}$, Ra. $4,460 \mathrm{calccm}^{-2}$ and Su: $22 \%$; Group III: Ta. $208^{\circ} \mathrm{C}$, Ra. $3,210 \mathrm{cal} . \mathrm{cm}^{-2}$ and Su $22 \%$; Group IV: Ta. $169^{\circ} \mathrm{C}$, Ra. $1,140 \mathrm{cal.cm}-{ }^{2}$ and Su $23 \%$

Herbicides that control magnoliopsida in soybean and corn cultures may have their use mitigated if conditions are altered at these proportions. However, the ones that act on poaceas, such as inhibitors of acetolactate-synthase (ALS) and acetyl-coenzyme-A carboxylase (ACCase), will be used more often, along with glyphosate, which has total action and may be applied to postemergence of transgenic cultures $\left(\mathrm{RR}^{\circledR}\right)$.

When climate conditions are decreases in temperature and radiation accumulation, with increase in soil moisture - cases of Groups III and IV - species have increases in emergence (Figure $3)$. In these conditions, the most favored and important species, in descending order, are sida, alexander grass, crab grass, beggartick and morning glory, with $241,202,147,20$ and 16 plants $\mathrm{m}^{-2}$, respectively. Thus, weed management with the use of herbicides would not change but there may be more pressure regarding selection and evolution of resistance.

\section{CONCLUSION}

Increase in soil temperature favors crab grass emergence, whereas it decreases emergence of alexander grass, morning glory, beggartick and sida. The main species that adapt to conditions of decrease in temperature and solar radiation are sida, alexander grass and crab grass. Decrease in radiation increases the frequency of magnoliopsida species and leads to faster establishment of all species in hilly soil.

\section{ACKNOWLEDGMENTS}

The authors would like to thank Conselho Nacional de Desenvolvimento Científico e Tecnológico (CNPq) for the scholarship.

To CNPq for the Research Fellowship of Dr. Dirceu Agostinetto/N.Proc. 308363/2018-3 CNPq.

The authors would like to thank Universidad de Costa Rica.

RESUMO: As informações climáticas permitem inferir qual será o nível de infestação de plantas daninhas, sendo que cada espécie exige requisitos específicos para ocorrência do processo germinativo. Objetivou-se avaliar as espécies infestantes e o fluxo de emergência de plantas daninhas em área de coxilha, quando submetidas a diferentes condições ambientais de temperatura e luz. Realizaram-se dois experimentos 
em delineamento inteiramente casualizado, com quatro repetições. No primeiro experimento os tratamentos foram definidos por cobertura com filme plástico (sem filme, filme somente em cima, parcialmente fechado e totalmente fechado) e, no segundo, por coberturas de polietileno preto $(0 ; 35 ; 50$; e $80 \%)$. A emergência de plantas daninhas na área foi monitorada diariamente, até estabelecimento do fluxo de emergência. Realizou-se também o monitoramento da temperatura do solo, interceptação da radiação solar e umidade do solo. Para a análise das espécies em cada tipo e nível de cobertura foram calculados os parâmetros fitossociológicos e o índice de velocidade de emergência. Os dados obtidos foram submetidos à análise de covariância e quando significativo procedeu-se o teste de Tukey $(\mathrm{p} \leq 0,05)$. Foi realizada análise de grupamento hierárquico para relacionar os fatores e os níveis experimentais aos intervalos da distribuição das covariáveis climáticas. $\mathrm{O}$ aumento em $8,5^{\circ} \mathrm{C}$ na temperatura do solo favorece a emergência de milhã, enquanto que reduz a emergência de papuã, corriola, picão-preto e guanxuma. As principais espécies a se adaptar as condições de redução da temperatura e radiação solar são guanxuma, papuã e milhã, sendo que a redução da radiação aumenta a frequência das espécies magnoliopsidas e proporciona o estabelecimento mais rápido de todas as espécies.

PALAVRAS-CHAVE: Germinação. Manejo. Mudanças climáticas.

\section{REFERENCES}

ALI, H. H.; TANVEER, A.; NADEEM, M. A.; ASGHAR, H. N.; JAVAID, M. M. Germination ecology of Rhynchosia capitata: an emerging summer weed in Asia. Planta Daninha, v. 31, n. 2, p. 249-257, 2013. http://dx.doi.org/10.1590/S0100-83582013000200002.

AMARAL, A.; TAKAKI, M. Achene dimorphism in Bidens pilosa L. as determined by germination test. Brazilian Archives of Biology and Technology, v. 41, n. 1, p. 11-16, 1998. http://dx.doi.org/10.1590/S151689131998000100002.

BARRETT, S.; LENTON, T. M.; MILLNER, A.; TAVONI, A.; CARPENTER, S.; ANDERIES, J. M.; CHAPIN, F. S.; CRÉPIN, A. S.; DAILY, G.; EHRLICH, P.; FOLKE, C.; GALAZ, V.; HUGHES, T.; KAUTSKY, N.; LAMBIN, E. F.; NAYLOR, R.; NYBORG, K.; POLASKY, S.; SCHEFFER, M.; WILEN, J.; XEPAPADEAS, A.; ZEEUW, A. Climate engineering reconsidered. Nature Climate Change, v. 4, n. 1, p. 527-529, 2014. https://doi.org/10.1038/nclimate2278.

CANOSSA, R. S.; OLIVEIRA, JR. R. S.; CONSTANTIN, J.; BRACCINI, A. L.; BIFFE, D. F.; ALONSO, D. G.; BLAINSKI, E. Temperatura e luz na germinação das sementes de apaga-fogo (Alternanthera tenella). Planta Daninha, v. 26, n. 4, p. 745-750, 2008. http://dx.doi.org/10.1590/S0100-83582008000400005.

CARDOSO, V. J. M. Germination studies on dispersal units of Sida rhombifolia L. Revista Brasileria de Botânica, v. 13, n. 2, p. 83-88, 1990.

CHIVINGE, O. A. Studies on the germination and seedling emergence of Bidens pilosa and its response to fertilizer application. Journal Transactions Zimbabwe Scientific Association, v. 70, n. 2, p. 1-5, 1996. https://www.cabdirect.org/cabdirect/abstract/19982300407.

GUIMARÃES, S. C.; SOUZA, I. F.; PINHO, E. V. R. V. Efeito de temperaturas sobre a germinação de sementes de erva-de-touro (Tridax procumbens). Planta Daninha, v. 18, n. 3, p. 457-464, 2000. https://doi.org/10.1590/S0100-83582000000300010.

IPCC (Intergovernmental Panel on Climate Change). Fourth Assessment Report: Climate Change 2007. Cambridge, Cambridge University Press, 2007. https://www.ipcc.ch/report/ar4/syr/. Acesso em: 26 jan. 2019.

KLEIN, A.; FELIPPE G. M. Efeito da luz sobre a germinação de sementes de ervas invasoras. Pesquisa Agropecuária Brasileira, v. 26, n. 7, p. 955-966, 1991. https://seer.sct.embrapa.br/index.php/pab/article/view/3428/761. 
MONDO, V. H. V.; CARVALHO, S. J. P.; DIAS, A. C. R.; FILHO, J. M. Efeitos da luz e temperatura na germinação de sementes de quatro espécies de plantas daninhas do gênero Digitaria. Revista Brasileira de Sementes, v. 32, n. 1, p. 131-137, 2010. http://dx.doi.org/10.1590/S0101-31222010000100015.

MUELLER-DOMBOIS, D.; ELLENBERG, H. A. Aims and methods of vegetation ecology. New York: John Wiley, 1974.

MURTAGH, F.; LEGENDRE, P. Ward's hierarchical agglomerative clustering method: which algorithms implement Ward's criterion?. Journal of Classification, v. 31, n. 4, p. 274-295, 2014.

https://doi.org/10.1007/s00357-014-9161-z.

MYERS, M. W.; CURRAN, W. S.; VANGESSEL, M. J.; CALVIN D. D.; MORTENSEN, D. A.; MAJEK, B. A.; KARSTEN, H. D.; ROTH G. W. Predicting weed emergence for eight annual species in the northeastern United States. Weed Science, v. 52, n. 6, p. 913-919, 2004. https://doi.org/10.1614/WS-04-025R.

ORZARI, I.; MONQUERO, P. A.; REIS, F. C.; SABBAG, R. S.; HIRATA, A. C. S. Germinação de espécies da família Convolvulaceae sob diferentes condições de luz, temperatura e profundidade de semeadura. Planta Daninha, v. 31, n. 1, p. 53-61, 2013. http://dx.doi.org/10.1590/S0100-83582013000100006.

POPINIGIS, F. Fisiologia da semente. $2^{\text {a }}$ ed., Brasília: Agiplan, 1985.

SALVADOR, F. L.; VICTORIA FILHO, R.; ALVES, A. S. R.; SIMONI, F.; SAN MARTIN, H. A. M. Efeito da luz e da quebra de dormência na germinação de sementes de espécies de plantas daninhas. Planta Daninha, v. 25, n. 2, p. 303-308, 2007. https://doi.org/10.1590/S0100-83582007000200009.

TAIZ, L., et al. Fisiologia Vegetal. $6^{\mathrm{a}}$ ed. Porto Alegre: Artmed, 2017.

WERLE, R.; BERNARDS, M. L.; ARKEBAUER, T. J.; LINDQUIST, J. L. Environmental triggers of winter annual weed emergence in the Midwestern United States. Weed Science, v. 62, n. 1, p. 83-96, 2014a. https://doi.org/10.1614/WS-D-13-00091.1.

WERLE, R.; SANDELL D. L.; BUHLER, D. D.; HARTZLER, R. G.; LINDQUIST, J. L. Predicting emergence of 23 summer annual weed species. Weed Science, v. 62, n. 2, p. 267-279, 2014b.

http://dx.doi.org/10.1614/WS-D-13-00116.1.

YODA, K.; KIRA, T.; OGAWA, H.; HOZUMI, K. Self-thinning in overcrowded pure stands under cultivated and natural conditions - intraspecific competition among higher plants. Journal of Biology Osaka City University, v. 14, p. 107-129, 1963. https://hdl.handle.net/2027/coo.31924066911607. 